\title{
IDENTIFIKASI KESALAHAN MAHASISWA TEKNIK INFORMATIKA DALAM MENYELESAIKAN SOAL STATISTIKA
}

\author{
Dharma Bagus Pratama Putra', Indana Lazulfa ${ }^{2}$, Iftitaahul Mufarrihah ${ }^{3}$ \\ ${ }^{1,2,3}$ Universitas Hasyim Asy'ari \\ dharmabaguspp@gmail.com ${ }^{1}$, indanazulf@gmail.com², \\ iftitaahul.mufarrihah@gmail.com ${ }^{3}$
}

\begin{abstract}
ABSTRAK
Penelitian ini bertujuan untuk mengidentifikasi kesalahan mahasiswa dalam menyelesaikan soal statistika. Penelitian dilakukan di Universitas Hasyim Asy'ari dengan subyek penelitian mahasiswa teknik informatika yang berjumlah 18 orang. Jenis kesalahan pada penelitian ini dibedakan menjadi tiga macam, yaitu kesalahan konsep, kesalahan strategi dan kesalahan hitung. Metode yang digunakan dalam penelitian ini adalah deskriptif kualitatif. Intrumen pengumpulan data adalah soal tes yang terdiri dari 6 soal dan wawancara tidak terstruktur. Hasil penelitian adalah mahasiswa melakukan 37 kasus kesalahan. Kesalahan konsep terjadi sebanyak $27,03 \%$ dari total kesalahan. Kesalahan strategi sebanyak 21,62\% dan paling banyak adalah kesalahan hitung sebesar 51,35\%. Faktor penyebab kesalahan mahasiswa bermacam-macam antara lain: kurang paham dengan konsep maupun rumus, kesulitan dalam memahami sintaks atau langkah-langkah pengerjaan, terburu-buru dan kesulitan dalam memperkirakan nilai akar kuadrat.
\end{abstract}

Kata kunci: identifikasi kesalahan, penyelesaian soal, soal statistika.

\begin{abstract}
This study is aimed to identify the student's error in solving statistical problems. This research was conducted at Hasyim Asy'ari University which those subject 18 peoples of informatics students.Student's errors in statistics are categorized into three types, which are: conceptual mistakes, strategy mistakes and calculation mistakes. The method used in this research is qualitative descriptive. The instruments to collect data are test questions which are consist of 6 equations and unstructured interviews. The result of this study is students doing 37 cases of error. Conceptual errors occur as much as $27,03 \%$ of the total errors. Strategy mistakes is $21,62 \%$ and the most is a calculation error of $51,35 \%$. The factors that cause student's error vary among others is : lack of understanding of concepts and formulas, difficulties in understanding the syntax or step by step of procedures, too rush in solving a problem and difficulties in estimating the square root value.
\end{abstract}

Keywords: student's mistakes identify, problem solving, statistics problems.

\section{PENDAHULUAN}

Kualitas pendidikan di Indonesia masih termasuk di bawah rata-rata kualitas pendidikan internasional.Berdasarkan hasil PISA (Programme for International Student Assessment) tahun 2015, Indonesia berada pada posisi 64 dari 72 negara (TIM Penyusun, 2017). Berbagai upaya dilakukan pemerintah untuk meningkatkan kualitas pendidikan di Indonesia. Salah satunya dengan 


\section{Dharma Bagus Pratama Putra', Indana Lazulfa ${ }^{2}$, Iftitaahul Mufarrihah ${ }^{3}$}

mengadakan INAP (Indonesia National Assessment Programme) yang bertujuan memetaan capaianpendidikan untuk memantau mutu pendidikan secara nasional.

Selain peranan pemerintah, kualitas pendidikan juga ditentukan oleh proses pembelajaran di instansi pendidikan. Media pembelajaran, metode pembelajaran dan kualitas guru terus dikembangkan untuk meningkatkan pembelajaran. Namun yang sering dilupakan adalah masalah pada obyek pembelajaran yaitu mahasiswa. Dengan melihat kualitas mahasiswa yang dihasilkan dapat disimpulkan bagaimana proses pembelajaran yang sudah terjadi.

Mahasiswa Teknik Informatika di Universitas Hasyim Asy'ari banyak yang mengalami kesulitan dalam matakuliah statistika. Berdasarkan hasil Ujian Akhir Semester (UAS) tahun ajaran 2017/2018 rata-rata nilai mahasiswa hanya mencapai 56. Dari hampir 40 mahasiswa, hanya 5 orang yang memiliki nilai di atas 70. Dari observasi pada saat pembelajaran, banyak mahasiswa yang mengalami kesalahan dalam perhitungan ketika matakuliah statistika. Bahkan ada mahasiswa yang melakukan operasi hitung $48: 8$ hasilnya adalah 8 . Kesalahan adalah suatu penyimpangan terhadap hal yang benar yang bersifat konsisten, sistematis dan insendental pada bidang tertentu (Sukirman, 2013). Kesalahan mahasiswa bermacam-macam. Menurut Imswastana dan Muhassanah (2016) ada empat macam kesalahan siswa yaitu a) kesalahan konsep, b) kesalahan strategi, c) kesalahan hitung, d) kesalahan sistematik. Indikator dari kesalahan konsep adalah mahasiswa tidak memahami konsep yang baik ( Imswatama \& Muhassanah, 2016). Kesalahan strategi terjadi karena mahasiswa memilih cara mengerjakan yang tidak tepat. Kesalahan hitung terjadi jika mahasiswa mengalami kesalahan dalam operasi matematika. Sedangkan kesalahan sistematik adalah kesalahan dalam hal pemilihan teknik ekstrapolasi.

Salah satu upaya untuk mengatasi kesulitan belajar adalah dengan menganalisis hasil tes dan mengidentifkasi kesalahan mahasiswa (Krismanto, 2006). Identifikasi kesalahan yang dimaksud dalam penelitian ini adalah mencari semua jenis kesalahan siswa dan mengelompokkannya berdasarkan jenis kesalahan. Dengan diidentifikasikan kesalahan mahasiswa maka akan lebih mudah bagi dosen untuk memberikan scaffolding. 
Statistika merupakan matakuliah wajib di Teknik Informatika. Statistika sebagai dasar ilmu mahasiswa untuk mengambil matakuliah lanjutan seperti Data Mining dan Basis Data. Mahasiswa juga membutuhkan Statistika terutama ketika proses penyusunan skripsi yang berhubungan dengan penelitian kuantitatif. Pada penelitian ini materi statistika yang dibahas adalah pengukuran data, lebih spesifiknya adalah ukuran pemusatan data.

\section{METODE PENELITIAN}

Penelitian ini merupakan jenis penelitian deskriptif. Pendekatan yang digunakan dalam penelitian ini adalah kualitatif deskriptif. Peneliti selain sebagai pengumpul data dan penganalisis data juga terlibat langsung dalam penelitian (Moleong, 2006). Fenomena yang diamati dan dikaji pada penelitian adalah kesalahan mahasiswa dalam mengerjakan soal statistika. Subyek penelitian adalah mahasiswa Teknik Informatika di Universitas Hasyim Asy'ari. Mahasiswa yang diambil adalah mahasiswa semester IV atau tingkat II sebanyak 18 orang. Mahasiswa semester IV dipilih karena sudah mendapatkan matakuliah statistika.

Instrumen dalam penelitian adalah soal tes dan wawancara tidak terstruktur. Wawancara dilakukan jika data dari hasil tes masih kurang. Prosedur penelitian dimulai dengan melakukan tes pada mahasiswa semester IV. Soal tes terdiri dari 2 soal utama dimana setiap soal terdiri dari 3 subsoal. Soal-soal tersebut tentang pengukuran data. Berikut adalah soal tes mahasiswa.

\section{Kerjakan Soal Berikut dengan tepat!}

1. Diketahui data populasiberikut: $\begin{array}{lllllll}1 & 4 & 8 & 1 & 2 & 1 & 5 .\end{array}$

Dari data tersebut.carilah:
a. rerata (mean)
b. median
c. modus

2. Diketahuinilai sampel 20 anak sebagai berikut

\begin{tabular}{|l|l|l|l|l|l|l|}
\hline Nilai & 5 & 6 & 7 & 8 & 9 & 10 \\
\hline Frekuensi & 1 & 4 & 5 & 3 & 5 & 2 \\
& & & & & \\
a. Carilah rerata dari data tersebut \\
b. Carilah variansi dari data tersebut. \\
c. Simpangan baku dari data tersebut
\end{tabular}
c.

Gambar 1. Soal tes mata kuliah statistika 
Hasil tes mahasiswa akan dianalisis dan diidentifikasi kesalahannya. Pada penelitian ini, kesalahan mahasiswa dikategorikan menjadi 3 jenis yaitu (Kastolan, 1992)

1. Kesalahan konsep dengan indikator menurut Kastolan (1992) :

a.) Kesalahan dalam penggunaan rumus/definisi dalam menjawab soal

b.) Menggunakan rumus/definisi yang tidak sesuai dengan kondisi atau prasyarat berlakunya rumus.

2. Kesalahan strategi dengan indikator menurut Kastolan (1992) :

a.) Dalam pengerjaan soal, langkah-langkah tidak sistematis

b.) Tidak dapat atau melakukan kesalahan dalam manipulasi langkahlangkah pengerjaan soal

3. Kesalahan hitung dengan indikator salah dalam operasi hitung seperti penjumlahan, pengurangan dan sebagainya.

\section{HASIL PENELITIAN DAN PEMBAHASAN}

Berdasarkan hasil jawaban tes oleh mahasiswa, berikut hasil analisis kesalahan mahasiswa dalam menyelesaikan soal statistika.

Tabel 1. Hasil Analisis Jawaban Mahasiswa

\begin{tabular}{ccccccc}
\hline \multirow{2}{*}{ Inisial Mahasiswa } & \multicolumn{7}{c}{ Jenis Kesalahan } \\
\cline { 2 - 7 } & 1a & 1b & 1c & 2a & 2b & 2c \\
\hline AM & Benar & Benar & Benar & Benar & Benar & Benar \\
MAM & Benar & Benar & Benar & Benar & Hitung & Hitung \\
EHA & Benar & Konsep & Benar & Benar & Strategi & Hitung \\
IA & Benar & Benar & Benar & Benar & Benar & Benar \\
S & Benar & Konsep & Benar & Strategi & Konsep & Konsep \\
AF & Benar & Benar & Benar & Hitung & Strategi & Hitung \\
UF & Benar & Benar & Benar & Strategi & Konsep & Konsep \\
TH & Benar & Konsep & Benar & Benar & Konsep & Hitung \\
TB & Benar & Benar & Benar & Benar & Hitung & Hitung \\
MPS & Benar & Benar & Benar & Benar & Benar & Benar \\
AR & Benar & Benar & Benar & Benar & Strategi & Hitung \\
FI & Benar & Benar & Benar & Benar & Strategi & Hitung \\
MS & Benar & Benar & Benar & Benar & Strategi & Hitung \\
\hline
\end{tabular}




\begin{tabular}{ccccccc}
\hline \multirow{2}{*}{ Inisial Mahasiswa } & \multicolumn{6}{c}{ Jenis Kesalahan } \\
\cline { 2 - 7 } & $\mathbf{1 a}$ & $\mathbf{1 b}$ & $\mathbf{1 c}$ & $\mathbf{2 a}$ & $\mathbf{2 b}$ & $\mathbf{2 c}$ \\
\hline HN & Benar & Benar & Benar & Benar & Strategi & Hitung \\
MSn & Benar & Benar & Benar & Benar & Konsep & Hitung \\
MSA & Hitung & Benar & Benar & Benar & Hitung & Hitung \\
RK & Benar & Benar & Benar & Benar & Hitung & Hitung \\
MRF & Benar & Benar & Benar & Benar & Konsep & Hitung \\
\hline
\end{tabular}

Mahasiswa yang mengalami kesalahan hitung pada soal nomor 1a sebanyak 5,56\%. Mahasiswa yang lain mengerjakan soal 1a dengan benar. Untuk soal nomor $1 \mathrm{~b}$, ditemukan 16,67\% mahasiswa yang mengalami kesalahan konsep. Sedangkan pada soal nomor 1c, tidak ditemukannya kesalahan pada hasil jawaban mahasiswa. Kesalahan strategi mulai dilakukan mahasiswa pada soal nomor 2a. Ada 11,11\% mahasiswa yang melakukan kesalahan strategi dan 5,56\% mahasiswa melakukan kesalahan hitung pada soal nomor $2 \mathrm{a}$.

Mahasiswa banyak membuat kesalahan pada soal nomor $2 \mathrm{~b}$ dan $2 \mathrm{c}$ yaitu sebanyak $83,33 \%$ mahasiswa. Pada soal 2 b, ada sebanyak $27,78 \%$ mahasiswa yang membuat kesalahan konsep, 33,33\% mahasiswa melakukan kesalahan strategi dan 22,22\% mahasiswa melakukan kesalahan hitung. Sedangkan pada soal 2c, ada sebanyak 11,11\% mahasiswa yang mengalami kesalahan konsep dan $72,22 \%$ mahasiswa mengalami kesalahan hitung. Berikut disajikan kesalahan mahasiswa dalam diagram batang.

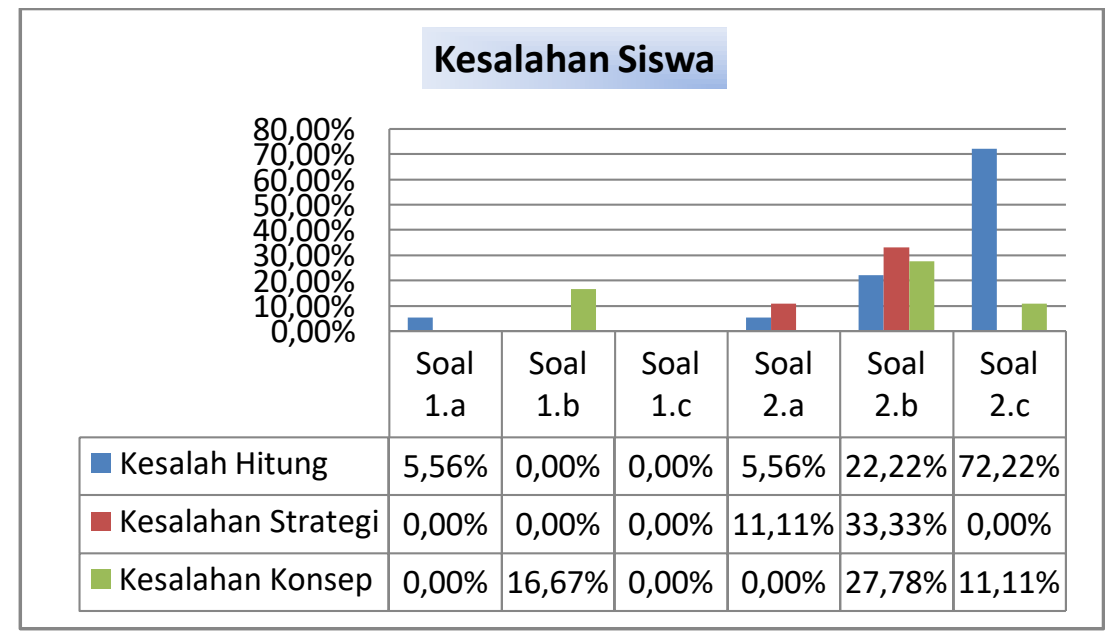

Gambar 2. Diagram Batang Kesalahan Siswa 
Berdasarkan Tabel 1 dari total 108 jawaban, mahasiswa membuat 37 kesalahan. Selain itu, kesalahan yang paling banyak dilakukan adalah kesalahan hitung yaitu sebanyak 19 kasus atau 51,35\% dari semua kesalahan. Hal ini sama seperti peneletian yang dilakukan oleh Arigiyati (2017) dimana mahasiswa paling banyak mengalami kesalahan komputasi/hitung yaitu 68,79\% (Arigiyanti, 2017). Berikut akan dibahas beberapa kesalahan mahasiswa dalam mengerjakan soal statistika.

\section{Kesalahan Konsep}

Kesalahan konsep yang terjadi antara lain kesalahan dalam konsep median dan variansi. Beberapa mahasiwa juga tidak paham dengan konsep variansi dan simpangan baku sehingga tidak bisa mengerjakan soal. Berikut merupakan contoh hasil pekerjaan siswa yang mengalami kesalahan konsep.

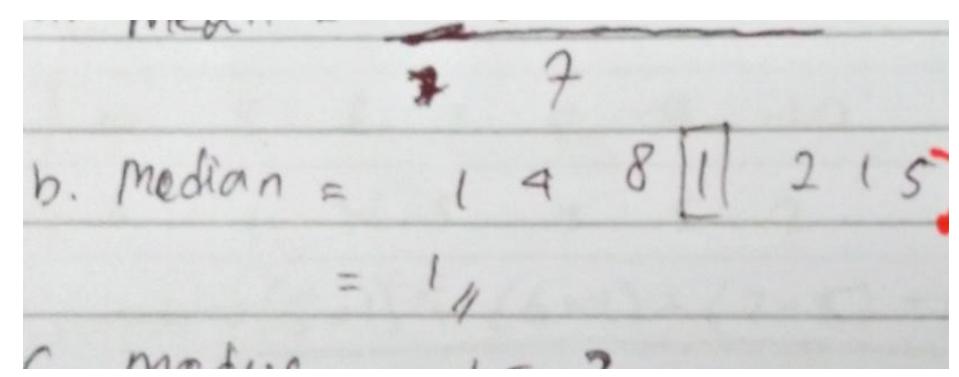

Gambar 3. Kesalahan Konsep Mahasiswa

Salah satu indikator kesalahan konsep menurut Kastolan (1992) adalah menggunakan rumus/definisi yang tidak sesuai dengan kondisi atau prasyarat berlakunya rumus. Dari Gambar 3, mahasiswa memahami median sebagai data yang terletak di tengah. Namun syarat definisi median tersebut adalah "setelah data diurutkan". Sehingga dapat dikatakan jenis kesalahan yang dilakukan mahasiswa tersebut adalah kesalahan konsep. Dari analisis didapatkan bahwa $27,02 \%$ dari kesalahan yang dilakukan mahasiswa adalah kesalahan konsep. Ketika dilakukan wawancara dengan mahasiswa yang melakukan kesalahan konsep, sebagaian besar menjawab karena tidak paham dengan rumus variansi. Beberapa orang lainya menjawab karena tidak tahu kalau median itu datanya harus diurutkan. 


\section{Kesalahan Strategi}

Kesalahan strategi yang dilakukan mahasiswa antara lain kesalahan dalam strategi mencari nilai total (pada proses mencari rata-rata) dan strategi mencari selisih nilai data dengan rata-rata (pada proses mencari nilai varian). Berikut adalah contoh pengerjaan soal siswa yang mengalami kesalahan strategi.

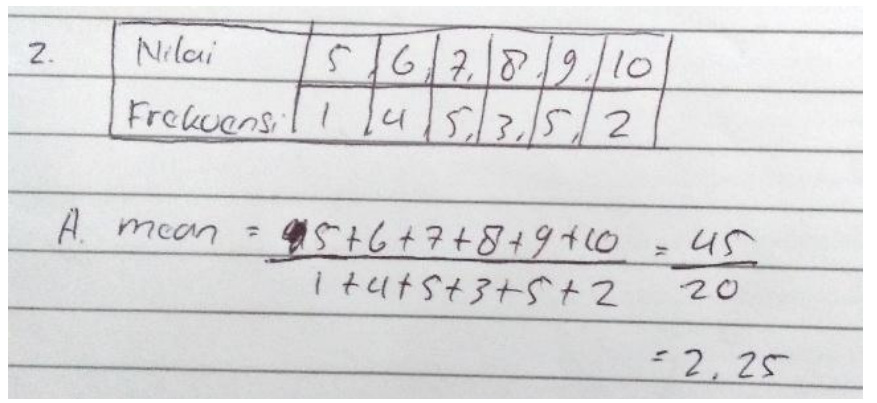

Gambar 4. Kesalahan Strategi Mahasiswa

Dalam mencari nilai total mahasiswa mengalami kesalahan. Mahasiswa melupakan bahwa nilai 6 frekuensinya adalah 4 sehingga dia melewati satu langkah yaitu mengalikan 6 dengan 4 atau menjumlahkan 6 sebanyak 4 kali. Menurut Kastolan (1992) salah satu indikator melakukan kesalahan strategi adalah tidak dapat atau melakukan kesalahan dalam manipulasi langkah-langkah pengerjaan soal. Sehingga mahasiswa tersebut melakukan kesalahan strategi. Kesalahan strategi yang dilakukan mahasiswa adalah 21,62\% dari total kesalahan. Ketika dilakukan wawancara dengan mahasiswa yang melakukan kesalahan strategi rata-rata mahasiswa menjawab karena kurang paham dengan rumus sehingga kesulitan dalam menentukan apa yang harus dicari terlebih dahulu.

\section{Kesalahan Hitung}

Seperti dibahas sebelumnya, kesalahan hitung merupakan kesalahan yang paling sering dilakukan mahasiswa yaitu $51 \%$ dari total kesalahan. Kesalahan hitung yang terjadi antara lain pembagian, penjumlahan dan pencarian akar. Berikut salah satu contoh jawaban mahasiswa yang melakukan kesalahan hitung.

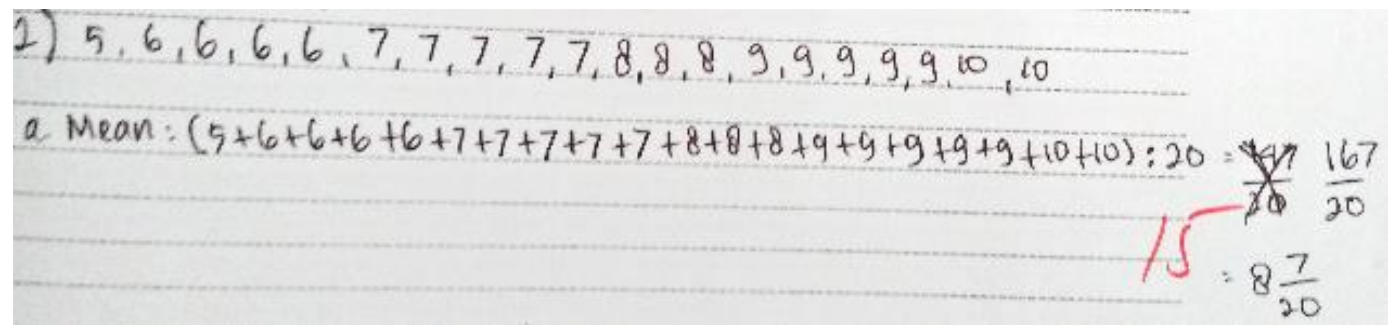

Gambar 5. Kesalahan Hitung Mahasiswa 
Ketika dilakukan wawancara pada mahasiswa yang melakukan kesalahan hitung banyak alasan yang mereka ungkapkan. Sebanyak 33,33\% dari mahasiswa mengatakan karena kurang teliti, 46,67\% yang mengatakan karena waktunya tinggal sedikit sehingga mereka terburu-buru dan sisanya mengakatan bahwa tidak bisa mencari atau memperkirakan nilai dari operasi akar kuadrat.

\section{SIMPULAN}

Dari hasil penelitian tentang identifikasi kesalahan mahasiswa dalam mengerjakan soal statistika dapat disimpulkan:

a. Kesalahan yang paling banyak dilakukan oleh mahasiswa adalah kesalahan hitung yaitu sebanyak 51,35\% dari total kesalahan kemudian kesalahan konsep sebanyak 27,03\% dan kesalahan strategi sebanyak 21,62\%.

b. Faktor penyebab kesalahan mahasiswa bermacam-macam antara lain: kurang paham dengan konsep maupun rumus, kesulitan dalam memahami sintaks atau langkah-langkah pengerjaan, terburu-buru dan kesulitan dalam memperkirakan nilai akar kuadrat.

\section{DAFTAR PUSTAKA}

Imswatama, A., \& Muhassanah, N. (2016). Analisis Kesalahan Mahasiswa dalam Menyelesaikan Soal Geometri Analitik Bidang Materi Garis dan Lingkaran. Seminar Nasional Matematika dan Pendidikan Matematika UNY. Yogyakarta: Universitas Negeri Yogyakarta.

Arigiyanti, T. (2017). Identifikasi Kesalahan Mahasiswa dalam Menyelesaikan Soal Pengantar Probabilitas. Jurnal Penelitian Pendidikan Vol 9 No 1, 1311-1374.

Kastolan, e. a. (1992). Identifikasi Jenis-jenis Kesalahan Menyelsaikan Soal-soal Matematika yang DIlakukan Peserta DIdik Kelas 2 Program A1 SMA Negeri Se-Kotamdya Malang. Malang: IKIP Malang .

Krismanto, A. (2006). Diagnosis Kesulitan Belajar Matematika SMP, Bahan Pelatihan Diklat Jenjang Lanjut. Yogyakarta: PPPG Matematika.

Moleong. (2006). Metodologi Penelitian Kualitatif . Bandung: PT Remaja Rosda Karya.

Sukirman. (2013). Identifikasi Kesalahan-Kesalahan yang Diperbuat Siswa Kelas 3 SMP pada Setiap Aspek Penguasaan Bahan Pelajaran Matematika. Dalam Wardoyo, Analisis Kesalahan Siswa Kelas X1 SMA Negeri 1 Cukup Tengah Dalam Menyelesaikan Masalah Divergen Tentang Sistem Persamaan Linear Dua Peubah (hal. 8-9). Bengkulu: Universitas Bengkulu. 
Identifikasi Kesalahan Mahasiswa Teknik Informatika dalam Menyelesaikan Soal Statistika

TIM Penyusun. (2017). Potret Pendidikan Indonesia : Statistika Pendidikan 2017. Jakarta: Badan Pusat Statistika. 